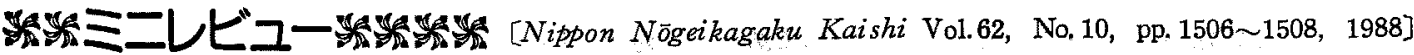

\title{
有用物質生産株の育種と分離
}

\author{
山田耕路, 川原浩治 \\ (九州大学费学部)
}

近年，動物培塄細胞を用いた有用物䓄生産の必要性吕 強く認識されるようになってきた、動物培買細胞を用い て物質生産を行うためには，をず，活発な増殖能を有し， 分化機能を効率的に発現する細胞株を分離・育種する必 要がある. 近年では動物細胞への遗伝子の導入が活発に 行われるようになり，動物培養細胞株を積極的に改変し ていこうとする試みがなされるよらになってきた。この ような細胞の育種に扣いて種々の技法が用いられ，その ための新しい装置の開発も進められてきた.ここでは, ヒト型ハイブリドーマ作製への応用例を用いて，電気融 合装置および自動細胞分取装置（七ルンーター）の細胞 㕕種への利用について解説する.

\section{1. 電気融合装置の遗伝子導入および細胞融合への利} 用

動物細胞への遺伝子導入法としてトシンスフェクショ ン法, リポソーム法, マイクロインジェクション法等が 用いられてきだ. 表1に示したように，これらの方法 にはそれぞれ一長一短が方り，いずれの方法を用いた場 合もすべての細胞に遺伝子を効就良く䙸入することは不 可能であった，たとえば，特別な機器および熟練を必要 としないことから広く用いられてきたトランスフェクシ ョン法はマウス L細胞のような頜食能の高い接着細胸に 抬いては高い遗伝子導入効率を与えるが，浮遊細胞には 適用することが困難であるとの難点を有していた。

一方，最近用いられるよらになってきた電気穿孔法は 電気的に細胞膜に穴をあけるため，浮遊細胞にも適用す ることが可能であり，遺伝子導入效率もトランスフェク ション法と比較するとかなり高い結果が得られる(2). 動 物細胞への遺伝子導入には $2 \sim 10 \mathrm{KV} / \mathrm{cm}$ の高電圧パル

t Isolation and Establishment of Cells Producing Biologically Active Substance.

Koji YAMADA and Hiroharu KaWAHARA (Department of Food Science and Technology, Faculty of Agriculture, Kyushu University, Higashiku, Fukuoka 812)
スが用いられるが，最適パルス強度は用いる細胞種，パ ルス発生装置, 緩衝液, 温度、DNA のサイズ等で翼な るので，実験に疬じて最適化を行ら必要がある。現在で は各社から電気パルス発生装監が市販されているが，上 級機種は次に述べるよらに動物細胞の電気融合装置とし ても利用することがでさるため，沉用性が高いといら利 点むある.また，同様な手法としてレーザー穿孔法 ${ }^{(8)}$ が開発され，市販至っているが，洒格が高いといら難 点がある. 本装置の最大の長所は細胞壁を有する細胞を 多穿孔して違伝子を導入することができる点にあり，プ ロトブラスト化が困難な植物細胞への遗伝子導入に高い 有効性を示するのと思われる。

1975 年に Köhler し Milstein によりマウスミェロー マとリンパ球の融合細胞（ハイブリドーマ）が作製され て以来(4)，種々の抗原に対する抗体を産生するマウス八 イプリドーマが数多く分離されてきた、これらのマウス 抗体は生体物質の㭘出, 分離・精製, 構造解析等に利用 され，種々のヒト疾病の診断にも有効であった。しか し，マウス抗体はヒトに対し抗原抗体反応を引き起こ し，副作用を示すこと，人体内では安定性が低いこと等 の久点を有しており，七ト疾病の治潦への応用にはかな りの困難を伴らことが明らかとなってきた(5). 礼れれれ は以上の難点を克服するためには，ヒト型抗体の利用が 最適であると考え：ヒト型ハイブリドーマの作製る行っ てきた(6,7).

通常, ハイブリドーマの作製にポリエチレングリュー ル (PEG) 法を用いているが(6)，われわれはさらに高い ハイプリドーマ出現效率を得るため，電気融合法を導入 し，その最適条件の設定を進めている。表 2 にヒト型八 イブリドーマ作製の実施例を示したが，大橋らによって 分離された HO-323 細胞 ${ }^{(9)}$ は他のヒト親細胞株と比べ， 高いハイブドーマ出現效率を与えるので，PEG 法で 6容易にハイブリドーマが得られる. しかし， HMy 2 細胞等のヒト親細胞株を用いた場 合, PEG 法ではハイ 
表 1 、各锤遺伝子道入法の長所および短所

\begin{tabular}{|c|c|c|c|}
\hline 遺伝子適入法 & & 所 & 短 \\
\hline トランスフェクション & & 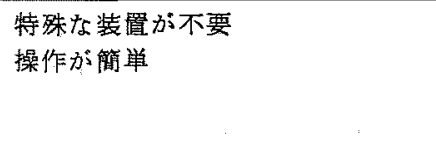 & $\begin{array}{l}\text { 効率が低い } \\
\text { 細胞の適用範囲が狭い } \\
\text { 高分子 DNA の尊入が困難 } \\
\text { 定量性が低い }\end{array}$ \\
\hline マイクロインシェクション & & $\begin{array}{l}\text { 核と細胞質を区別して導入しうる } \\
\text { 效率が高い } \\
\text { 細胞の適用筙囲が広い } \\
\text { 定量性が高い }\end{array}$ & $\begin{array}{l}\text { 装置が高洒である } \\
\text { 操作に熟練を要する } \\
\text { 多数の細胞を取り扱えない } \\
\text { 無菌性の保持が困難 }\end{array}$ \\
\hline リポソーム・赤血球ゴースト融合法 & & $\begin{array}{l}\text { 特殊な装置が不要 } \\
\text { 細胞の兽用範困が広い } \\
\text { 定量性が高い }\end{array}$ & $\begin{array}{l}\text { 効率が低い } \\
\text { 高分子 DNA の導入が困難 }\end{array}$ \\
\hline レーザー穿孔法 & & $\begin{array}{l}\text { 操作が簡単 } \\
\text { 效率が高い } \\
\text { 細胞の適用範囲が㕕い } \\
\text { 細胞壁に穿孔可能 }\end{array}$ & 装酎が高洒である \\
\hline 電気穿孔法 & & $\begin{array}{l}\text { 操作が簡単 } \\
\text { 效率が高い } \\
\text { 細胞の適用䈚囲が広い }\end{array}$ & \\
\hline
\end{tabular}

表 2 PEG 法就よ゙゙電気融合法によるとト型ハイブリドーマ作製例

\begin{tabular}{|c|c|c|c|c|}
\hline 親細胞 & 融合法 & $\begin{array}{l}\text { パルス電压 } \\
(\mathrm{kV} / \mathrm{cm})\end{array}$ & $\left(\times 10^{7}\right.$ 細胞 $\left./ \mathrm{ml}\right)$ & $\begin{array}{l}\text { イフブリドーマ出現効寗 } \\
\text { (クローン/10 }\end{array}$ \\
\hline $\mathrm{HO}-323$ & PEG & - & 3.0 & 1.10 \\
\hline HMy-2 & PEG & - & 3.0 & 0.10 \\
\hline \multirow[t]{4}{*}{$\mathrm{HMy}-2$} & 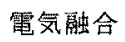 & 2.0 & 1.0 & 0.48 \\
\hline & & 2.0 & 3.0 & 0.35 \\
\hline & & 2.3 & 1.0 & 0.48 \\
\hline & & 2.3 & 3.0 & 0.50 \\
\hline
\end{tabular}

ブリドーマ出現効率が低く，抗原特異的単クローン抗体 を生産するハイブリドーマを得ることは非常に困難とな る.しかし，電気融合法を用いた場合，HMy 2 細胞で もハイブリドーマ出現効率が向上し，PEG 法による HO-323 の結果に近い倠が得られた。この結果は高いハ イブリドーマ出現効率を得るためには優秀な親細胞を用 いることが重要であることを示しているだけでなく，電 気融合条件の最適化を行うことにより出現効率をさらに 向上さ㹥うることを示している. 現在, 電気融合法の最 適条件の設定にはハイブリドーマ出現効率を指標として 用いているが，この方法では結果が得られるまで約 2 週 間を必要とするだけでなく，得られる数值も細胞融合効 率とハイブリドーマのクローニング效率をかけあわせた むのにすぎないこれらの数値を個々に求めるためには 次に述ベるセルソーターの利用が必要となる.
2. セルソーターによる細胞集団の解析および細胞の 分取

サイトフルオロメーターは細い水流中を流れる個々の 細胞にレーザー光線を照射し，細胞により散乱されるレ 一ザー光やレーザー光により励起されて細胞より放出さ れる蛍光を測定することにより，細胞の大きさ，形状， 表面棈造，細胞成分含量等を分析する装置である。さら に，セルンーターに岕いては，分析された細胞集団から 任意の性質を有する細胞集団のみを分取する機能が付加 されている。

ハイブリドーマは大型の親細胞と小型のリンパ球が融 合して生じるので，細胞融合により得られる細胞集団を セルソーターを用いて解析すると，細胞の大きさ（前方 散乱)，細胞の形状括よび複稚さ(側方散乱)，DNA 含量 特よびB 細胞表面抗原量（いずれも営光分析）等が異な る複数の細胞集団が得られる。このセルンーターの分析 
機能を用いることにより，細胞融合効率を迅速に溳定す ることができる。ま，ハイプリドーマのみを分取し， 96 穴培荃プレートに1個す゚つまきこんで培盖すること によりコロニー形成率る容易に求めることができる。

ハイブリドーマ作製のためのリンハ球源としては末梢 血，脾淢，偏桃腺，リンパ節等が用いられるが，概して 末梢血リンパ球を用いるハイブリドーマ出現效率性低い ことが多い(10)，その原因として末梢血リンパ球にはハイ ブードーマの出現を阻害する suppressor T細胞执よび cytotoxic T細胞の比率が高く，B細胞の抗体産生を促 進する helper T細胞の比率が低いこと，京たB細胞自 身も抗体産生に必要な活性化を受故難い状態にあること 等が指摘岕机ている(11).このよ5な系を用いてハイブリ ドーマの作製を行う場合はセルソーターを用いてリンパ 球を分画し，必要な細胞のみを融合に使用することによ りハイブリドーマの出現效率を上昇させることが可能と なる。

図 1 に細胞集団の解析・分取の実施例を示した. ヒト 亲梢血リンパ球をフィコエリスリン (PE) 標識抗ヒト B 細胞抗体和上び FITC 標識抗七トT細胞抗体で二重染 色した後セルソーターを用いて解析した，B細胞は PE で染色され，T細胞はFITCで染色された結果，2つの 異なる細胞集団と乙て画面上で識別可能となっている. 困1はさらにそれぞれの細胞集団を分取するための領域 設定 (ゲーティング)を行った画面を示して括り，この 設定に従って2つの細胞集団を同時に別々の容器に回収 することができる、このよらな生体由来の細胞は自家虽 光が少なく，細胞集団の解析・分取を容易に行うことが

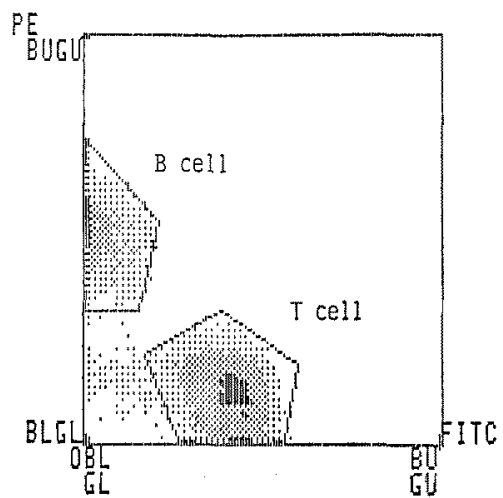

図 1 セルソーターによるヒトB拉よびTりンパ球 の分取
できるが，培養細胞はFITC の蛍光波長領域付近に強い 自家萤光を持つため，PE 標識抗体を使用する必要があ る場合が多い，しかし，現在市販されている抗体の多く はFITC 標識抗体であるため，今後培養細胞を用いた細 胞集団の解析が活発化するためには培䖯細胞の解析に使 用しうる種々の萤光摽識抗体が供給される必要がある。 また，抗原特異的抗体を産生するハイブリドーマを直接 スクリーニングする方法へのセルソーターの利用も考克 られている(12).すなわら，虽光標識した抗原をアビシンー ビオチン法で特異的抗体を産生しているB細胞（抗体が 細胞膜表面に発現している) に結合させた後細胞融合を 行い, 萤光標識されたハイブリドーマのみをセルソータ 一で分取する試みがなされている.

ここではハイブリドーマ作製実験への応用例について 述べたが，七ルソーターは目的とする細胞を虽光標識す ることができれば，種々の細胞のクローニングに利用す ることができる、したがって，本装置は今後初代培着細 胞あるいは翼伝子導入等により人為的に得られた細胞集 団から特定の細胞表面マーカーを有する細胞の分離・育 種に利用されていくるのと思われる。

（1）山田耕路：「細胞制御工学」, 学葖社, 1986, p. 49.

（2）稻葉浩子，葛西道生，佐藤弘毅：蛋白質 核酸 醅素，32，10（1987）。

（3）粕尾敬宏, 塚越幹郎, 山田 豊: 生命工学研究 レポート，4，1 (1985).

(4) G. Köhler and C. Milstein : Nature, 256, 495 (1975).

（5）入江礼子，八田光弘：蛋白質 核酸 酵素，31, 1501 (1986).

(6) H. Murakami : "Biotechnology of Mammalian Cells," Japan Scientific Societies Press/ Springer-Verlag, 1987, p. 119.

(7)山田耕路, 村上浩紀: 発 醉之工業, 45, 218 (1987).

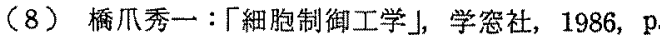
107.

(9) H. Ohashi, S. Hashizume, H. Murakami, K. Aihara, K. Shinohara and H. Omura: Cell Biol. Int. Rep., 10, 77 (1986).

(10) K. James and G. T. Bell : J. Immunol. Methods, 100, 5 (1987).

(11) C. A. K. Borrebaeck : Trends Biotechnol., 4, 147 (1986).

(12) D. M. Wajchowski and A. J. Sytkowski : J. Immunol. Methods, 90, 173 (1986). 